\title{
What Has Cordilleran Spirituality to Do with Evangelicals?
}

\author{
Francis Jr. S. SAMDAO \\ Philippine Baptist Theological Seminary, Philippines
}

\begin{abstract}
This article brings out some aspects of the Cordilleran primal spirituality of the northern Philippines and two vital lessons for Evangelicals influenced by the Enlightenment worldview. Evangelicals in the West tend to dichotomize the supernatural realm and the natural world. Their propositional spirituality and individualistic lens have shaped many Filipino Evangelicals. In this essay, I use a hermeneutic of appreciation of culture since it is a vital interlocutor of Christian theology. I argue that Cordilleran spirituality has something to contribute to evangelical Christianity. Of particular interest are the Cordilleran view of the existence of spirits and their hermeneutical community.
\end{abstract}

\section{Keywords}

Cordillerans, Igorots, Spirit world, Cañao, Evangelicals

\section{INTRODUCTION}

I am an evangelical Christian, and my roots are in Mainit Bontoc, Mountain Province, Philippines, a land blessed with breathtaking nature and astonishing hot springs. It is an honor to be part of the so-called "Igorots," indigenous people in the Cordillera, Northern Luzon. William Henry Scott, quoting the Third District representative of Mountain Province, Luis Hora, states that the term Igorot was invented by the Spaniards to ridicule the highlanders they failed to conquer. ${ }^{2}$ However, the designation Igorot may

1 I will use the terms "Igorot/s" and "Cordilleran/s" interchangeably.

2 William Henry Scott, "The Word Igorot,” Philippine Studies 10, no. 2 (1962): 234. 
be an indigenous term meaning "mountaineer." 3 Others would say that the Cordilleran people have taken this nomenclature from a foreign tribe. ${ }^{4}$

Igorots are a people rooted in the beautiful mountains created by God, or Kabunian/Cabunian, and entrusted with rich traditions, spirituality, and culture. Some Christians may criticize me for using the term Kabunian. Such criticism is understandable, since not all Igorot Christians agree if it is proper to equate Kabunian with the Supreme Being. For some, the use of Kabunian to refer to the Creator God is acceptable, but for others, it is not since it is a name of a pagan god. Suffice it to note that the term is still the subject of an ongoing discussion among the Cordilleran Christians, in the same way as the use of gong in Christian worship. Hence, I will leave that issue since it is beyond the scope of this article.

Many Filipino lowlanders imagine an Igorot as small, dark, possessing a tail, and living in huts on the mountains. Some people in Manila even use Igorot as a derogatory term. Unfortunately, this misunderstanding has been found in some elementary textbooks in the Philippines. I wrote this article at the height of the controversy regarding the caricatures of Igorots in the Department of Education's learning materials. This ignorant depiction of our identity as natives of the Cordillera united the Cordilleran leaders to take action. ${ }^{5}$ Many Cordillerans joined the \#iamproudigorot challenge on Facebook.

While I hope to present the Igorot identity as accurately as possible, I also believe that one has to be nuanced in responding to these discriminatory and wrongful depictions. My aim is to provide a sketch of the rich cultural heritage and spirituality of the Igorots. I do not contend that Cordilleran spirituality is the point of reference for evangelical Christianity concerning the spirit world. I endeavor to explicate some things that the latter may gain from the former. To set the backdrop, I will first discuss the Cordillera

3 Scott, "The Word Igorot": 248.

4 Carl Wilhelm Seidenadel, The First Grammar of the Language Spoken by the Bontoc Igorot: With a Vocabulary and Texts, Mythology, Folklore, Historical Episodes, Songs (Chicago: The Open Court Publishing Company, 1909), 21, https://babel.hathitrust.org/cgi/ pt?id=uiug. $30112078926158 \&$ view $=1$ up\&seq $=77$ (accessed February 15, 2021).

5 S Baguio, "Cordillera lawmakers unite vs erroneous modules," Sun Star Baguio, https: / / www.sunstar.com.ph/article/1885314/Baguio/Local-News/Cordilleralawmakers-unite-vs-erroneous-modules, February 8, 2021 (accessed February 13, 2021). 
region, then explore some Igorot beliefs, and finally, expound two main contributions to Evangelicals.

\section{The Cordillera Region}

The Cordillera is a region with a chain of mountains composed today of six neighboring provinces: Abra, Apayao, Benguet, Ifugao, Kalinga, and Mountain Province. ${ }^{6}$ The Cordillerans include various tribes. According to A. L. Kroeber, the major tribes are the Kankana-ey, Ibaloi (Nabaloi), Ifugao, and Bontok. ${ }^{7}$ He did not include the people in Kalinga, Abra, and Apayao, perhaps because his observation was made in the early 1900 s. The Cordillerans are composed of ethno-linguistic groups such as Bagos, Bontoks, Ibalois, Ifugaos, Isneg, Kalingas, Kankana-eys, and Tinguians. ${ }^{8}$

During the Spanish colonization (1565-1898), the Igorots resisted the entry of these foreigners. They refused to let the Spaniards seize the land and natural resources they had inherited from their ancestors. As a result, the Spaniards failed to subjugate the Cordillerans despite their forty-five attempts to explore the mountains. This failure made them demean the Cordillerans as lazy, hostile, and barbaric pagans. ${ }^{9}$ Such portrayals are quite different from that of another foreigner, C. R. Moss, who describes the Benguet natives as known for their hospitality and generosity. For him, the Igorots were pleasant company with a keen sense of humor. They were also diligent because of the need to toil in their elevated environment. ${ }^{10}$

The Cordillerans inhabit a fruitful land that provides food for sustenance and cohabit with "other" beings. They were successful in formalizing their

6 Gerard A. Finin, The Making of the Igorot: Contours of Cordillera Consciousness (Quezon City, PH: Ateneo De Manila University Press, 2005), 8.

7 A. L. Kroeber, Kinship in the Philippines (New York: The Trustees, 1919), $\quad 75, \quad$ https:// babel.hathitrust.org/cgi/pt?id=loc.ark:/13960/ t08w4880n \&view $=1$ up\&seq $=11 \& q 1=$ Igorot $($ accessed February 15, 2021).

8 Tereso C. Casiño, “The Clash between 'Our Father' and the 'Mothers and Fathers' of the Cordillerans in Northern Philipines," Torch Trinity Journal 9, no. 1 (November 2006): 101.

9 Ma. Luisa Aguilar-Cariño, "Igorot as Other: Four Discourses from the Colonial Period," Philippine Studies 42, no. 2 (1994): 194.

10 C. R. Moss, Nabaloi Law and Ritual (Berkeley: University of California Press, 1920), 212, https: / / babel.hathitrust.org/ cgi/ pt?id=hvd.32044041907890\&view=1up\&seq=14 (accessed February 14, 2021). 
ownership of their sacred ancestral lands with the Philippine State, ${ }^{11}$ which is only proper since they defended these territories and resources (especially the Igorot gold mines) against the Spaniards. Intriguingly, Scott writes:

Modern writers of the Republic of the Philippines had been almost as slow as their Spanish predecessors to give credit to the Igorots for this defense of their territory, and lecturers in college classrooms in the nation's capital have been known to dismiss the accomplishment as a simple accident of geography or international politics - that is, that it was too much trouble for the Spaniards to invade the rugged mountains or that they didn't want to do so in the first place. ${ }^{12}$

Many women in the Cordillera, especially in Ifugao, enjoyed equality with men before the Western concepts of femininity and masculinity were imposed. ${ }^{13}$ Concerning the appearance of the Igorots, Fray Pedro de Vivar, a Western missionary, comments, "although their bodies are almost the same as the Ilocanos', they are well developed and of better build than the other islanders ... They are very strong, which is especially remarkable in the women and children . . . they have wonderful endurance on the trail and hike with no strain." ${ }^{14}$

The arrival of the American Protestants, particularly the Episcopalians (1902), ${ }^{15}$ in the Cordillera paved the way for the establishment of Englishspeaking schools. The twenty to thirty years of colonization, the schools, and the efforts of the missionaries made the natives learn the English language, including their ancestors who did not study formally. ${ }^{16}$ The Americans were also instrumental in restricting the headhunting practices

11 Deirdre McKay, "Rethinking Indigenous Place: Igorot Identity and Locality in the Philippines,” The Australian Journal of Anthropology 17, no. 3 (2006): 291.

12 William Henry Scott, "Igorot Responses to Spanish Aims: 1576-1896," Philippine Studies 18, no. 4 (October 1970): 702-703, http:/ /www.philippinestudies.net/files/ journals / 1 / articles / 1150/public/ 1150-3505-1-PB.pdf (accessed February 14, 2021).

13 Margarita R. Orendain, "Woman in Ifugao Traditional Stories," Saint Louis University Research Journal 25, no. 2 (December 1994): 384.

14 Fray Pedro de Vivar, trans., William Henry Scott, "Account of the Establishment and State of the New Missions in the Igorot Nation: Containing What Happened from February 1755 to April 1756," Philippine Quarterly of Culture \& Society 16 (1988): 162.

15 Julie C. Ma, When the Spirit Meets the Spirits: Pentecostal Ministry among the Kankana-ey Tribe in the Philippines, rev. ed. (Eugene, OR: Wipf \& Stock, 2001), 52.

16 McKay, "Rethinking Indigenous": 296. 
of the people. ${ }^{17}$ Among other achievements, these foreigners have built roads, established Baguio City as the Summer Capital of the Philippines, and developed Sagada Mountain Province. But I do not romanticize the contributions of the Americans to the Cordillera. Their ethnocentric lens assumed the Cordillerans to be ignorant, primitive, and animistic. ${ }^{18}$ They failed to grasp that the lives of the Igorots connect to Mother Naturethat is, Cordillerans' perspective of relationship extends to the land they inhabit. ${ }^{19}$ This is a kind of worldview common to Filipinos. They perceive thinking and doing, philosophy and religion, culture and spirituality as one reality. ${ }^{20}$

\section{The SPIRIT WorLd OF THE Cordillerans}

Every November 1, most Filipinos visit the cemeteries, and TV programs such as "Magandang Gabi Bayan" (Good Evening Motherland/ Countrymen) of ABS CBN, and GMA's "Kapuso Mo, Jessica Soho" (One at Heart, Jessica Soho) always feature a "Halloween Special." They depict ghost stories from different places and various people in the country. Most Filipinos watch these programs not just because they are entertaining, but because they also recount the Filipino spirit world, including the Cordilleran spirituality.

The Cordillerans had been practicing their own primal religion long before the arrival of Spaniards and the Americans. The Igorots believe in the existence of the Supreme God, named Kabunian. Under this powerful being are minor deities such as Lumawig, Bangan, Kabigat, and others. ${ }^{21}$ The

17 Biano L. Baucas, Traditional Beliefs and Cultural Practices in Benguet (Benguet, PH: New Baguio Offset Press, 2003), 88.

18 Analyn Salvador-Amores, "Afterlives of Dean C. Worcester's Colonial Photographs: Visualizing Igorot Material Culture, from Archives to Anthropological Fieldwork in Northern Luzon," Visual Anthropology 29, no. 1 (2015): 55, https: / www.tandfonline. $\mathrm{com} / \mathrm{doi} /$ full/10.1080/08949468.2016.1108832 (accessed February 12, 2021).

19 Dinah Elma Piluden-Omengan, Death and Beyond: Death \& Burial Rituals \& Other Practices \& Beliefs of the Igorots of Sagada, Mountain Province, Philippines (Quezon City, PH: Giraffe Books, 2004), xiv, 1.

20 George N. Capaque, "Spirituality for Asian Contexts: The Philippines and Beyond," in Walking with God: Christian Spirituality in the Asian Context, ed. Charles Ringma and Karen Hollenbeck-Wuest (Manila: OMF Literature Inc., 2014), 58.

21 Eufronio L. Pungayan and Isikias T. Picpican, "Rituals and Worship among the 
Bontoc people named Lumawig as the creator of the earth and humanity but consider him inferior to Kabunian. ${ }^{22}$ Kate Botengan considers Lumawig to be the son of Kabunian, and the former taught the Bontoc people arts, skills (such as fighting, irrigation, planting), and religious beliefs. ${ }^{23}$

The spirit worship of the Cordilleran primal religion is ubiquitous. For instance, these gods are embedded in the folk songs and dances of the Ibalois in Benguet. Their traditional songs call on the gods for healing and harm to their enemies. ${ }^{24}$ Ritual dance such as Palis serves to drive away evil spirits and to cure a sick person. ${ }^{25}$

The manifestations of the spirituality of the Cordilleran people are ubiquitous in their daily activities. There is no demarcation between the secular and spiritual. Their animist religion upholds the importance of being in tune with the ecosystem-a "sacramental" perspective. Even animals have souls, and when they die, they join the spirits of their owners. ${ }^{26}$ Since Mother Nature helps the Cordillerans grow as a self-sufficient community, their lifestyle must preserve nature, respect inanimate objects, and value their neighbors. In short, Cordilleran daily rituals and practices are closely linked to their religion, promoting communal and cooperative

Benguet Igorots," Saint Louis University Research Journal 9, nos. 3-4 (1978): 463. Mona Bias, an Old Testament scholar who belongs to the kankana-ey and Ibaloi tribes, posits that the highest God is the Adi Kaila (Unseen Being) and Kabunian is the second-highest God. Mona P. Bias, "Contextualization in an Ethnic Culture," in The Gospel in Culture: Contextualization Issues through Asian Eyes, ed. Melba Padilla Maggay (Manila: OMF Literature Inc., 2013), 283-284. However, in the Mountain Province where I came from, Kabunian is the Supreme and Creator God, and I contend that the Adi Kaila is a general term referring to the unseen beings. Even the five authors of Ibaloi Conversations on Identity, Community, and Well-Being write that Kabunian is the Supreme Being. Sofia Olga Anton, et al., Ibaloi Conversations on Identity, Community and Well-Being (Baguio City, Philippines: TEBTEBBA, 2010), 13.

22 Joy Christine O. Bacwaden, "The Culture Hero of the Bontoc-Igorot," Philippine Studies 45, no. 3 (1997): 333, 341, http://www.jstor.org/stable/42635050, (accessed February 14, 2021). Bontoks spell it Kafunian.

23 Kate Chollipas Botengan, Bontoc Life-Ways: A Study in Education and Culture, ed. Paz Policarpio Mendez and F. Landa Jocano (PH: Capitol Publishing House, Inc., 1976), 21.

24 Maria Hazel Valdez, "Reflections of Culture in the Folk Songs of the Benguet Ibalois," Saint Louis University Research Journal 25, no. 1 (June 1994): 96.

25 Remigio E. Monroe, Jr. "Igorot Dances Associated with Rituals and Ceremonies: An Analysis and Interpretation” (Ed.D. diss., Baguio Central University, 1987), 54.

Moss, Nabaloi Law, 273. 
existence..$^{27}$ In addition, agricultural cycles such as planting, waiting, and harvesting; political matters such as the settling of land disputes, territorial disagreements, and trials for crimes; and building houses are attached to the spirit world. ${ }^{28}$

In Bontoc, people regard the unseen beings as part of the world in which they find themselves. The animals they raise, the crops they plant, and other activities are not detached from the guidance of their ancestors. ${ }^{29}$ Some important rituals or celebrations always include butchering pigs or chickens for the consumption of the people and with the invisible beings. During the Ani (rice harvest) and Saknit (sugarcane harvest) seasons, some of their essential rites are prayers and the offering of a piece of meat and native wine. Bontoc people also observe a Sabbath or a day (or days) of rest called Te-er (Tengao for other tribes). This is a sacred time due to some religious performances associated with sickness, crops, climate, and others. Therefore, it is taboo to work in the field or to leave and enter the village. Visitors found entering would have to offer a pig, a chicken, or firewood. ${ }^{30}$

The spectrum from birth to the afterlife is a cycle within this kind of worldview. ${ }^{31}$ Life goes beyond death because dead people continue to exist, traveling with the winds and clouds. ${ }^{32}$ To some Cordillerans, it is essential to offer animals when a family member dies. The animal offering is part of a ritual so that the dead loved one will not harbor ill feelings against the living relatives. ${ }^{33}$ If a person gets sick, it is assumed that the spirits of the dead elders have been offended. Hence, to take proper action, the family

27 Anton et al., Ibaloi Conversations on Identity, 14.

28 Arun W. Jones, "A View from the Mountains: Episcopal Missionary Depictions of the Igorot of Northern Luzon, the Philippines, 1903-1916," Anglican and Episcopal History 71, no. 3 (September 2002): 393.

29 Pablo Filog, "The Tengao Custom of Bontoc: Its Meaning and Functions," Saint Louis University Research Journal 8, no. 1 (March 1977): 63-64.

30 Filog, "The Tengao": 38-40.

31 Jones, "A View from the Mountains": 393.

32 Mona P. Bias, "Consulting the Medium of Endor: Parallels and Analogies," in Principalities and Powers: Reflections in the Asian Context (Mandaluyong City, PH: OMF Literature Inc., 2007), 101.

Piluden-Omengan, Death and Beyond, 19. 
needs to know what made the ancestral spirits angry. ${ }^{34}$ An example of prayer from the people of Bontoc says:

Sika ay panteo anna

Paprakem nan likhat mi

Tsakayo at katsaksakran

Iyawid yu nan naay apo yu

Ta wad-ay sumassaaran yu.

English translation:

You who it is this door

Repel all our troubles

You who are our ancestors

You return this your grandchild

So that he will live longer

And you will have someone to be returning home to. ${ }^{35}$

Piled on this prayer is the importance of offerings to the unseen beings. If the sick person dies, she or he has failed to provide enough sacrifice. ${ }^{36}$

The Cordillerans inhabit the world together with their ancestors, spirits, inanimate objects, and nature. They believe that fortunes, blessings, illnesses, and disasters have connections to the spirit world, which is why rituals are vital in the lives of the Cordilleran people. These descriptions do not mean to constrict the complex ancestral domain of the Cordillerans. The assimilation of Christianity, the influence of technology, and the upbringing of the next generation of Igorots in different urban places make the Cordilleran beliefs colorful.

\section{The Cañao Ritual}

The Cordillerans communicate with their gods in different ways. One is the ceremony called cañao, a very sacred practice mediated by a native priest or Mambunong/Mambunung. ${ }^{37}$ Accordingly, "The term cañao has

34 L. P. Verora, Reaching the Igorots (Makati, PH: World Vision Philippines, 1982), 81-82.

35 Botengan, Bontoc Life, 23.

36 William Henry Scott, The Discovery of the Igorots: Spanish Contacts with the Pagans of Northern Luzon (Quezon City, PH: New Day Publishers, 1974), 193.

37 Pungayan and Picpican, "Rituals and Worship": 480. 
never been used as an Ibaloi word. The original terms used when referring to said celebration is kedot, kesheng, silbi or digat. It was in recent years that the term 'cañao' came about, which was perhaps of foreign origin." ${ }^{38}$ The cañao is a practice to appease or ask for help from Kabunian. Appeasement is needed for calamities that beset the people, while help is sought for healing and blessings ${ }^{39}$ An English translation of a Mambunong's prayer goes:

Thou, Cabunian who gave us this prayer in order to cure ourselves, you kindly see that it is for the good. If we happen to fail in something in our prayer, it is you who can fill it for us. If we have overly uttered something, then it is you who must discount such things. Give also this host (household) good blessing in their planting and domestication. ${ }^{40}$

The Cordillerans also practice cañao to communicate with their ancestral spirits called Ka-apuan. They do this by sacrificing animals with the help of a native priest. The ritual includes performing some traditional practices such as playing gongs and other instruments. ${ }^{41}$ Bias notes, "Some people in Benguet, whether educated or not, try to communicate with their dead relatives or ancestors. For minor cases, they may do it themselves by simply uttering a prayer. But in more complicated cases, they will seek the help of a mambunong." ${ }^{2}$ The Benguet's native priests have three offices, known as Mansip-ok, Mankot-om, and Mambunong. The Mansip-ok examines the sickness and prescribes the necessary ritual. The Mambunong performs the needed ritual that would heal a sick person. Mankot-om interprets omens and signs, which the other two (Mambunong and Mansip-ok) cannot do. ${ }^{43}$ This kind of ceremony is not limited to the inhabitants of Benguet. The people in Bontoc Mountain Province, Ifugao, Kalinga, and other Igorot tribes believe in powers and principalities. They interact with the unseen beings and the spirits of their ancestors.

There are other reasons for performing cañao. One is to give thanks for the blessings received, such as abundant harvest and good health. Others

38 Anto, et al., Ibaloi Conversations, 14.

39 Pungayan and Picpican, "Rituals and Worship": 463.

40 Pungayan and Picpican, "Rituals and Worship": 492.

41 Mona P. Bias, "Contextualization in an Ethnic Culture," 274.

42 Bias, "Consulting the Medium," 109.

43 Bias, "Contextualization in an Ethnic Culture," 288. 
may also perform a cañao to commemorate a death anniversary, wedding celebrations, healing for sickness, and others. On this occasion, it is essential to butcher animals such as pigs, carabaos, and cows. The sacredness of this celebration shows that not everyone is authorized to perform the ritual. The indigenous priest or priestess is the only authority to lead the ceremony accompanied by dancing, prayers, and singing. ${ }^{44}$

Other purposes of caña in ancient times are called Bendiyan cañao and Palis cañao. The former is a practice where the people celebrate the taking of heads of the enemies, while the latter refers to a ritual to counter witchcraft. ${ }^{45}$ The cañao ritual is not an individual private endeavor. It is a communal affair in which each family helps in the preparation. Also, neighbors, friends, and relatives from near and far come and join the ceremony. The yelling of pigs, the sound of gong and drums signal the start of the festivity. ${ }^{46}$ If there are visitors in the community, they are welcome to participate in the dances called Tayaw and Bendian. ${ }^{47}$ Also, communal participation is not restricted to the neighbors but also extends to the ancestors. Hence, native priests cover the first dance of cañao with prayers since this practice is a communion with the ancestors. After that, the youth, the guests, and others may participate in the dancing. ${ }^{48}$ The songs narrate worship of the gods, the importance of family, respect for the dead, and other things. ${ }^{49}$

\section{A Communal Hermeneutic}

I have provided some information about the hermeneutical community of the Cordillerans as seen in the caña ritual. It is not an individualistic ritual between a person and his or her gods, because individualism is an alien concept. This communal interpretive lens does not lie only in this ritual. For instance, my mother is an excellent weaver; many of my Kakailyan (people

44 Anton et al., Ibaloi Conversations, 14.

45 Other types of cañao are not mentioned in this article. See Valdez, "Reflections of Culture": 114 .

46 Anton et al., Ibaloi Conversations, 15-16.

47 Gabriel Pawid Keith and Emma Baban Keith, Kabayan Mummies: A Glimpse of Benguet (Baguio City, PH: Baguio Printing \& Publishing Company, Inc., 1981), 3.

48 Anton et al., Ibaloi Conversations, 15.

49 Valdez, "Reflections of Culture": 102. 
from our tribe/province) ask her to weave a Bahag (G-string). I learned from her that Cordillerans' G-strings vary from one tribe to another. Bontoc's Bahag is different from that of the Ibaloi's, and so too with the Ifugao's. This is important because it depicts the diverse cultural identity of the Igorots and the specific tribe they belong to. In short, G-String for the Cordillerans is not a piece of simple clothing or a costume, but it identifies the person with a specific community. Different G-strings indicate a Cordilleran's identity with a particular tribe.

My mother also weaves the burial clothing or blanket. In my province, we call it Ewes Nan Natey (blanket for the deceased). Different cultures in the Cordillera have various death practices. Nonetheless, it is common to have specific clothing depending on the beliefs associated with burial attire. ${ }^{50}$ Melba Maggay, a Filipino anthropologist, asserts that this clothing is essential during the burial because it represents the community or clan of the deceased. She explains that without this clothing or blanket, the spirit of the person would wander into the afterlife with no identity. ${ }^{51}$

Practices such as the cañao, burial clothing, and traditional songs convey the value of respecting the dead. That is because Cordillerans believe that ancestral spirits can bestow blessings to the community. Also, the dead ancestors may serve as mediums so that the prayers of the living reach the gods. In general, the Cordilleran communal lens recognizes the "cloud of witnesses" that paved their way. Again, the rudimentary belief is that the spirits of the dead join the ancestors in the mountains - meaning that dead relatives do not leave the rice fields, animals, and their tribe, and from time to time, they mingle with the living. ${ }^{52}$ If people know some places where spirits dwell, they do not want their names called out loud because the unseen will entice their souls to stay in those places. ${ }^{53}$

If the Filipino lowlands have the practice of Bayanihan ${ }^{54}$ to portray their unity and communal spirit, the Cordillerans' "Cooperative work was well-

50 Piluden-Omengan, Death and Beyond, 17.

51 Melba Maggay, "Towards Contextualization from Within," in Doing Theology in the Philippines (Manila: OMF Literature Inc., 2005), 48.

52 Filog, "The Tengao Custom": 63.

53 Scott, The Discovery of the Igorots, 193.

54 Bayanihan is a Filipino practice that expresses group work or unity by helping each other. See Gertrudes R. Ang, "The Bayanihan Spirit: Dead or Alive?," Philippine Quarterly of Culture \& Society 7, (1979): 91, https://www.jstor.org/ 
portrayed through the aduyunan, a system in which the community would voluntarily participate at work on the farm or in building somebody's house." ${ }^{5}$ The communal effort is not limited to building structures. Add to this is the transmission of traditions and values to the next generation. The elders believe in the necessity of transmitting the community's values to the next generation. ${ }^{56}$ Perhaps the significance of the Dap-ay (in some provinces they call it Ato or Avowan) in the lives of the Cordillerans proves their communal hermeneutic. A Dap-ay is a stone-paved gathering place for elders, bachelors, and boys. ${ }^{57}$ This place also serves to educate young men regarding culture, beliefs, and practices. In Benguet, there were communal houses for girls and boys, although they no longer exist today. ${ }^{58}$

In summary, Cordilleran rituals, practices, and values reveal a worldview in which the spirits of their ancestors, kinship, language, and community are intimately connected with the land..$^{59}$

\section{Learning From the Cordilleran WORLDVIEW}

José M. De Mesa, a Filipino Catholic theologian, emphasizes the necessity for the Filipinos to understand and appreciate their local cultures with their own eyes. ${ }^{60}$ That means removing the stigma that outsiders have attached to their ethnic cultures. Edgar Ebojo, an evangelical minister and author, reasons that foreign missionary trailblazers in the Philippines did not emphasize the spiritual worldview. Their focus was on their propositional worldview shaped by scientific and rational explanationsthe Enlightenment perspective. Hence, their theological issues, cultural

stable / 29791626?seq=1 (accessed May 30, 2021).

55 Anton et al., Ibaloi Conversations, 14.

56 Anton et al., Ibaloi Conversations, 14.

57 William Henry Scott, "The Legend of Biag, An Igorot Culture Hero," Asian Folklore Studies 23, no. 1 (1964): 100, https://asianethnology.org/downloads/ae/pdf/a149. pdf (accessed February 14, 2021).

58 Moss, Nabaloi Law, 214.

59 See Robeline T. Padsico, "Between the Living and Unseen Spirits: Documentation of the Practice of 'Am-med' and 'Bayani' in Kapangan, Benguet' (Thesis, Benguet State University, 2013).

60 José M. De Mesa, José M. De Mesa: A Theological Reader (Manila: De La Salle University Publishing House, 2016), 57. 
baggage, and residue affected the gospel they presented to the Filipinos. ${ }^{61}$ Much evangelical theology in the West assumes a modern epistemology that reduces the dynamic and animated world to a mathematical, cold, and mechanistic planet. ${ }^{62}$ Their understanding of the world diminishes into the parameter of "natural laws" under the mastery of reason and empirical observation. In contrast, the Cordilleran worldview can contribute to evangelical thought in two areas: the spirit world and a communal perspective.

\section{Recovering the Spirit World}

The modern period with its science as lingua franca ${ }^{63}$ sowed doubt about the world of spirits in the minds of Western Christians. A New Testament professor from the West who served in the Philippines confesses that, although he believes in the biblical account of demonization, his Western worldview hinders him from recognizing the reality of spirit beings. ${ }^{64}$ Samantha Miller, a professor of the history of Christianity, admits that the Western church, except for the charismatic groups, is uncomfortable discussing the reality of demons, spirits, and angels ${ }^{65}$ Perhaps that shows why much of Western theology neglects demonology. It seems that such

61 Edgar B. Ebojo, “The 'Other-Worldly' in the Hands of the 'This-Worldly' Scribes," in Principalities and Powers (Manila: OMF Literature Inc., 2007), 203-204. The pentecostal missionaries who came at a later period starting in 1947 are the exception, since they introduced a spiritual worldview: healing, casting out demons, God's power, and others to the Kankana-ey (Ma, When the Spirit Meets the Spirits, 74).

62 James K. A. Smith, "Is There Room for Surprise in the Natural World? Naturalism, the Supernatural, and Pentecostal Spirituality," in Science and the Spirit: A Pentecostal Engagement with the Sciences, ed. James K. A. Smith and Amos Yong (Bloomington, IN: Indiana University Press, 2010), 36.

63 This is to say that modernity is a secular dominion that makes humanity the arbiter of reality. Science becomes the tool to measure reality. With the help of science, humans are to master and control nature. See Stanley J. Grenz, "Star Trek and the Next Generation: Postmodernism and the Future of Evangelical Theology," in The Challenge of Postmodernism: An Evangelical Engagement, $2^{\text {nd }}$ ed., ed. David S. Dockery (Grand Rapids, MI: Baker Academic, 2001), 76.

64 Michael Andress, "An Experience with Demon Possession: A Case Study," Philippine Journal of Religious Studies 2 (1996): 2.

65 Samantha Miller, Chrysostom's Devil: Demons, the Will, and Virtue in Patristic Soteriology (Downers Grove, IL: IVP Academic, 2020), 1. 
a topic is left to Pentecostal Christianity. ${ }^{66} \mathrm{I}$ am not saying that North American Evangelicals deny the existence of demons and angels, but I am pointing out that this kind of topic is marginalized, especially in their textbooks on systematic theology. ${ }^{67}$ Larry W. Caldwell, a longtime professor at Asia Graduate School of Theology (AGST) and Asia Theological Seminary (ATS) who studied under Millard Erickson, notes that Erickson's magnum opus has not tackled one important issue in the lives of Asians, which is the spirit world. Erickson devotes twelve pages to such topics as "evil angels" and "the powers" and says nothing about such things as ancestral veneration. ${ }^{68}$

Perhaps twenty-first-century readers may find the Cordilleran spirit world strange. Nonetheless, despite the ubiquity of technology and science, there is still a universal belief that we are not the only ones here and that there exists a realm that we cannot see. ${ }^{69}$ This is vital since many foreigners come to do mission work in the Cordillera, and "some western missionaries find it difficult to address the issue because of their lack of knowledge and adequate training in handling the issue of ancestral cult." ${ }^{\text {"70 }}$ Those who desire to minister to the Cordillerans (and Asians generally) are too quick to label such a belief as "evil" or "from Satan." A Cordilleran scholar at Saint Louis University argues that, "Be it a folk superstition or mystery, these must be understood and appreciated according to the people's socio-cultural beliefs and practices." ${ }^{.71}$ Establishing a relationship

66 Wonsuk Ma, '“'In Jesus' Name!' Power Encounter from an Asian Pentecostal Perspective," in Principalities and Powers: Reflections in the Asian Context (Manila: OMF Literature Inc., 2007), 35.

67 Rodney L. Henry, Filipino Spirit World: A Challenge to the Church (Manila: OMF Literature Inc., 1986), 17-19. Some of the exceptions are the evangelical missiologists and counselors such as Paul Hiebert, Neil T. Anderson, Edward F. Murphy, and others.

68 Larry W. Caldwell, "How Asian is Asian Theological Education?," in Tending the Seedbeds: Educational Perspective on Theological Education in Asia, ed. Allan Harkness (Quezon City, PH: Asia Theological Association, 2010), 28-29.

69 Robert Munson, Ministry in Diversity: Applied Cultural Anthropology in a Multicultural World (Baguio City, PH: MM Musings, 2016), 7.

70 Casiño, “The Clash”: 102.

71 Isikias Picpican, The Igorot Mummies: A Socio-Cultural and Historical Treatise (Quezon City, PH: Rex Book Store Inc., 2003), 4. 
with the community and understanding their beliefs and practices provide a good platform for a fruitful dialogue.

It is also beneficial for Cordilleran pastors to study their culture. Many of the living ancestors regretted that the next generation's conversion to Christianity made them ashamed of their culture. Christians have a message that Jesus Christ is Lord over the material and the spirit realms. However, disrespecting the culture creates resistance for the older folks, not to mention that some Cordilleran Evangelicals regard belief in principalities and powers as mere "superstitions."

Ministers would do well to listen to Bias: "The timing to implement changes or make improvements on existing concepts is very important and must be considered." 72 After appreciating the practices and values of the community, ministers in the Cordillera region can " $t]$ race the reasons behind these practices and get to the principles behind them.... Find appropriate substitutes to these practices that do not encourage syncretism." ${ }^{\prime 3}$ For example, instead of performing cañao, one may do a thanksgiving service. Instead of offering prayers to Kabunian or the Adi Kaila, a Cordilleran may address the Creator God. Also, the wearing of Bahag at a wedding or in a gathering, especially if it is in the province, is commendable. Furthermore, Christianity asserts that Jesus is the high priest, the only mediator between humans and God, and the perfect sacrifice for the sins of humanity. Hence, there is no need to sacrifice animals to appease God. Therefore, Cordilleran ministers may teach that Jesus Christ is the high priest who mediates between the people and the living God. So, instead of butchering a chicken to appease the spirits, the Cordillerans can go to God directly in the Name of Jesus Christ.

While I disagree with the kind of contextualization that promotes tribal theologies disconnected from the catholicity of the church, Christians need to understand that "[o]ur first task in approaching another people, another culture, another religion, is to take off our shoes for the place we are approaching is holy. Else we may find ourselves treading on [people's] dreams. More seriously still, we may forget that God was there before our arrival. ${ }^{\prime 74}$ Asians should not be doing contextual theology just for the sake

72 Bias, "Contextualization," 330.

73 Bias, "Consulting the Medium," 117.

74 José de Mesa, quoting Bishop Kenneth Cragg. José M. de Mesa, "Cultural Analysis 
of making names for themselves or simply to resist Western hegemony. Asians are to be sensitive to the culture and to contextualize because theology is not without a context. ${ }^{75}$ Nonetheless, they must embrace a catholic sensibility to contribute to the larger body of Christ. ${ }^{76}$ This is to say that in doing theology, for and in the Cordillera, is not just a matter of focusing on Cordilleran cultural resources but also connecting it to the larger body of Christ guided by Scripture and the Christian tradition found in the Creeds and confessions. For example, one cannot just contextualize in the Cordillera without considering Christian creedal claims that God is Trinity, Jesus is the Son of God, and so forth.

\section{Recovering a Catholic Sensibility}

As discussed above, the Cordillerans value and treasure the importance of their rich heritage, identity, and community. Simon Chan correctly notes, "Primal religions can positively impact evangelical Christianity through their emphasis on a more holistic and communal nature of existence." 77 Perhaps evangelical Christians may learn from the relational concept of the Cordillerans. Christians should not neglect their historical continuity within their tradition. Also, they do not only belong to a local church but are also part of the larger community of God since the Church transcends space and time-a "transcendental reality." 78

Sadly, many Evangelicals do not appreciate their past. They are not acquainted with how their doctrines developed into what they are now. Even the distinguished historian A. G. Haykin affirms that many

and Inculturation in the Lowland Filipino Context," in A Universal Faith?: Peoples, Cultures, Religions, and the Christ: Essays in Honor of Prof. Dr. Frank De Graeve, ed. Catherine Cornille and Valeer Neckebrouck (Belgium: Peeters Publishers, 1992), 123.

De Mesa, José M. de Mesa, 48.

76 Chan offers a good critique of privatized religion in evangelical spirituality. He espouses the necessity for the people of God to understand that they are a worshiping community. Simon Chan, Liturgical Theology: The Church as Worshiping Community (Downers Grove, IL: IVP Academic, 2006).

77 Simon Chan, "Asian Christian Spirituality in Primal Religious Contexts," in Walking with God: Christian Spirituality in the Asian Context, ed. Charles Ringma and Karen Hollenbeck-Wuest (Manila: OMF Literature Inc., 2014), 40.

78 Simon Chan, "Mother Church: Toward a Pentecostal Ecclesiology," The Journal of the Society for Pentecostal Studies 22, no. 2 (Fall 2000): 177. 
Evangelicals are ignorant and suspicious of the ancient fathers. ${ }^{79}$ This results in a consumerist and individualistic proclivity accentuating that Christians may pick and choose what they believe, like selecting clothes in the malls. Tribal cultures like that of the Cordillerans seem to appreciate historical continuity more than most of those who claim to be Christians. ${ }^{80}$

Christianity is a communal relationship. Therefore, the Christian life is not just a matter of "me and Jesus." Even the contemporary Filipino Evangelicals' view of Christianity has been influenced by the Western modernist paradigm that neglects the communal life approach. James K. A. Smith observes that contemporary Christianity today, particularly modern Evangelicalism, has made the individual the basic component of the church. As such, the church becomes a mere collection of individuals whose fundamental theology is "Jesus come into my heart" or "me and God alone." This assumes that faith is unmediated by the church and thereby reduces the church to a place of fellowship for individuals who romanticize private relationships with God. Such ecclesiology fails to account for the essential role of the church in the formation of these individuals. ${ }^{81}$ With that, Evangelicals should appreciate the link of their faith to the global church and those who have gone before them (catholicity). As Chan espouses, "The spiritual life is not just about one's personal relationship with God. There is a corporate dimension which is supremely realized in the church especially through its worship and liturgy." ${ }^{\text {2 }}$

I do not declare that the church saves sinners; repentance and confession of Christ's lordship are the core of soteriology. However, Evangelicals should not forget that their roots go back beyond the Reformation. As such, it is vital to understand that they stand on the shoulders of saints who preceded them. They traverse the present because of the help of the church fathers. Therefore, to navigate the future, they need to learn from ancient wisdom. Knowing their rich historical heritage would hopefully produce a "maturing evangelical spirituality" through countering the privatized

79 Michael A. G. Haykin, Rediscovering the Church Fathers: Who They Were and How They Shaped the Church (Wheaton, IL: Crossway, 2011), 13.

80 Maggay, "Towards Contextualization from Within," 48.

81 James K. A. Smith, Who's Afraid of Postmodernism? Taking Derrida, Lyotard, and Foucault to Church (Grand Rapids, MI: Baker Academic, 2006), 29.

82 Simon Chan, "New Directions in Evangelical Spirituality," Journal of Spiritual Formation \& Soul Care 2, no. 2 (2009): 220. 
religion and consumerist mentality that is rampant today." ${ }^{33}$ This may also remind theologians that since theology is a communal exercise, they are to do theology not only for academics but also for the church. Therefore, theological sources necessitate the inclusion of the wisdom of Christians in the past. ${ }^{84}$

\section{Conclusion}

I have explained some of the essential aspects of the Cordilleran worldview, particularly their perception of the spirit realm and their communal perspective. The life of the Cordilleran people is best appreciated when one understands their spirit world. That is because their religioncall it pagan or animistic - permeates the way they perceive reality, whether political, economic, or social. The influence of technology on the next generation of the Cordillerans and the modernist worldview that the North American Evangelicals have transported into Asia have caused tribal beliefs to be dismissed as "satanic" or archaic. Even so, the Cordilleran worldview is rich with resources able to dialogue with the Evangelicals, particularly their tendency to capitulate to modern enlightenment presuppositions and individualism. In addition, it is vital for a minister in the region to understand and appreciate Cordilleran beliefs in order to serve the people effectively.

So, what has the Cordilleran worldview to do with Evangelicals? Cordilleran spirituality may nudge the evangelical consciousness on two themes. First, it reminds many evangelical Christians of something that is neglected in theological discussions - the spirit world. Second, the Cordilleran worldview prompts Evangelicals to treasure their ancient spiritual heritage.

\section{About author}

Francis Jr. S. SAMDAO is a teaching fellow at Philippine Baptist Theological Seminary and a ThD candidate at the Asia Baptist Graduate Theological Seminary.

83 Chan, "New Directions in Evangelical Spirituality": 220.

84 Stanley Hauerwas, "How I Think I Learned to Think Theologically," American Catholic Philosophical Quarterly 88, no. 4 (2014): 649-450. 


\section{Book Reviews}

David Jasper and Ou Guang-an, Literature and Religion: A Dialogue between China and the West (Eugene, OR: Pickwick Publications, 2020), ix + 176 pp., ISBN 978-1-5326-5218-9, \$24, paperback.

\section{Reviewer: LAI Pan Chiu The Chinese University of Hong Kong, Hong Kong}

Literature, history, and philosophy are conventionally considered the most important intertwined components of Chinese humanities. Given the rich literary and religious traditions of China, it is quite natural to expect that "religion and literature" should be an important research area in the Chinese studies of religions. However, in contemporary Chinese academia, while there are many historical and philosophical studies of Christianity, the studies of Christianity and literature are relatively few. Even fewer are the comparative or dialogical studies of literature and religion in Chinese and Western perspectives. The book under review fills this vacuum with a series of dialogues or experiments conducted by David Jasper, a wellestablished scholar of Christianity and literature, and Ou Chang-an, a relatively young literature scholar interested in religion.

The book itself exhibits a dialogical structure. Apart from the introduction and concluding reflections, it consists of two main parts. The first part, titled "From East to West," includes three essays from Ou Quangan. Each of them is followed by a response from Jasper.

The first chapter is a comparative study of Zhuangzi and the book of Job offered by Ou. He admits that the similarities between Zhuangzi and the book of Job are more related to the literary style, especially the employment of fictional narratives (14), than to their views on religious or philosophical issues such as suffering and fate (28). In fact, what $\mathrm{Ou}$ attempts to highlight are precisely their stark contrasts: whereas the book of Job maintains a staunch faith in God, Zhuangzi advocates a more passive 
attitude of "doing nothing" and comes closer to Stoicism. Jasper's response elaborates the contrasts made by Ou and goes further by making references to the retelling of the book of Job in Western literature, especially the novels by Muriel Spark.

In the third chapter, Ou continues the inquiry of fate by examining Thomas Hardy's Tess of the D'Urbervilles (1891) from a Chinese perspective. Ou's analysis of the novel highlights Tess as a victim of fate, even though Hardy himself might not believe in fatalism. Ou's analysis makes references not only to the relevant concepts of "fate" or "destiny" in Chinese culture, especially in Confucianism and Taoism, but also to the relevant background in Greek tragedy. In response to Ou, Jasper elaborates the literary background in Greek tragedy as well as the historical background of late Victorian "loss of faith," but he also wonders whether ancient Chinese culture could have a tragic figure comparable to Tess.

In the fifth chapter, Ou turns to William Butler Yeats (1865-1939), focusing on how his poetry reflects the change of his critical stand on Roman Catholicism and inclination toward Protestantism, especially the Church of Ireland. Ou's study of Yeats makes no explicit references to Chinese religion or literature, except for a brief mention of a Chinese scholar's study of Yeats. Jasper's response shifts the focus to Yeats's play Purgatory (1939), especially the Nietzschean character of its interpretation of purgatory.

The second half, titled "From West to East," appears to be more theologically oriented. Instead of focusing on a Western theological issue or literary work, in chapter 7 Jasper starts the dialogue with a sketch of the issues involved in Sino-Christian theology, an intellectual movement in contemporary China. The issues include the relationship between Christianity and Chinese culture, Christianity and nationalism, nonreligious interpretation of Christianity, and Christian interpretation of Chinese classics. Being an outsider of the movement, Ou's response emphasizes the inseparability of literature, history, and philosophy within the Chinese tradition, and thus the subordination of the study of religion under philosophy in Chinese academia, which allows for certain theological methods, including the "scriptural reasoning" associated with Sino-Christian theology. 
The second essay from Jasper is a study of Lu Xun (pen name of Zhou Shuren, 1881-1936), one of the best-known writers in modern China. Through analyzing various works of Lu Xun, including "A Minor Incident," which is a relatively overlooked short story but reminiscent of the parable of the Good Samaritan (Luke 10:30-37), Jasper argues that given Lu Xun's motivation of "save the nation," especially the "soul" or "spirit" of his nationals, through literary works, it is possible to regard $\mathrm{Lu}$ Xun as a religious writer offering spiritual medicine for the soul. In his response to Jasper, Ou points out that Lu Xun's effort as a whole is quite understandable against the Chinese cultural tradition as well as his own contemporary context, but Lu Xun's literary works also disclose certain "universal human moments."

In chapter 11, Jasper attempts to decipher the theology implied in some modern Chinese fictions. In addition to Lu Xun's works, Jasper's essay also covers Yu Hua's To Live (1993) and Chronicle of a Blood Merchant (1996), Yan Lianke's Serve the People! (2005) and Dream of Ding Village (2006), Gao Xingjian's Soul Mountain (1990), and others. With reference to the Taoist spirituality of seeking liberation, Jasper drives home the view that literature and theology cannot be separated, especially in the task of liberation. Ou's response supplements that apart from Taoism, Confucianism also plays an important role in the Chinese spiritual tradition and is embodied in, for example, Lu Xun's literary works. Finally, Ou briefly mentions Buddhism and its role in premodern Chinese literature such as Journey to the West, which is reminiscent of Gao Xingjian's Soul Mountain.

In the concluding reflections, Jasper makes references not only to Gao Xingjian's Soul Mountain to highlight the importance of freedom in literature, but also to James Legge's translation of The Book of Changes to underline the difficulties in crosscultural translation and yet to a deeper and fundamentally human commonality that may contribute to the overcoming of these difficulties. Ou then further elaborates these issues with numerous references to Chinese and Western literature and concludes with an "optimistic" note about the future of Sino-Christian theology.

There are several observations or comments to be made about the book in order to indicate that the experimental dialogues conducted in this book can inspire a lot of further investigations in this research area. 
First, as the book itself acknowledges, the materials are restricted to those available in English (5). This might be due to the limitation that one of the dialogue partners is not well equipped to read Chinese (148). In spite of this limitation, the book demonstrates a variety of approaches to conducting dialogue in this area. While Jasper's essays in the second part exhibit rather consistently an approach to decipher the theology implied in the literary works by non-Christian Chinese writers, Ou's three essays adopt three different approaches. The first one is on the comparison between a Western text and a Chinese text, and the second a reading of a Western text from a Chinese cultural/religious/philosophical perspective. The third concerns Christianity and Western literature, without significant reference to Chinese literature or religion.

Second, regarding the comparison between ancient Chinese and Western texts, the choice of texts is driven mainly by the similarity of literary style rather than by religious ideas. This may make one wonder whether Ecclesiastes, with its ideas about "fate" and "proper time," should be a better alternative for comparison with Zhuangzi, if the choice could be based on religious ideas rather than literary style.

Third, the references to Chinese culture or religions are mainly from Confucianism and Taoism, while Buddhism, which features rather prominently in Chinese literature, is largely omitted.

Fourth, as the book itself acknowledges, none of the Chinese writers referred to this book is Christian (4). It is rather well known that Christianity features in many modern Chinese literary works, and some modern Chinese writers are themselves Christians. Some studies of Christianity and modern Chinese literature have been published in English. A notable example not included in the bibliography of the book under review is Lewis Stewart Robinson, Double-Edged Sword: Christianity \& 20th Century Chinese Fiction (Hong Kong: Tao Fong Shan Ecumenical Centre, 1986). It is important to note that the literary works of Chinese Christian writers, such as Xu Dishan (1893-1941), might exhibit some sort of "fusion of horizon" between the Chinese and Christian (or Western) perspectives. See Chan Wai-keung, "Transcending Differences between Christianity and Buddhism with Love: The Life and Literary Works of Xu Dishan," Ching Feng, n.s., 6, no. 1 (2005): 53-75. 
There are some minor bugs. First, about Chinese names, there are some cases of mixing up family names with personal names. For example, in the bibliography, "Kam, Louie" should be "Louie, Kam," whose Chinese name is Léi Jīn Qìng in pinyin. A more glaring example is the running head that features "Guang-an" instead of "Ou," the family name of the author. Second, the book keeps using "Nestorianism" to refer to "Jing Jiao" (literally luminous religion), which was established by missionaries of the church of the East during the Tang dynasty and should not be called "Nestorianism" pejoratively.

LAI Pan Chiu

Professor in the Department of Cultural and Religious Studies, The Chinese University of Hong Kong. 